\title{
Asymptomatic malaria, growth status, and anaemia among children in Lao People's Democratic Republic: a cross-sectional study
}

Takeshi Akiyama ${ }^{1,2^{*}} \mathbb{0}$, Tiengkham Pongvongsa ${ }^{3}$, Souraxay Phrommala ${ }^{4}$, Tomoyo Taniguchi ${ }^{5}$, Yuba Inamine ${ }^{1}$, Rie Takeuchi ${ }^{6}$, Tadashi Watanabe ${ }^{7}$, Futoshi Nishimoto ${ }^{8}$, Kazuhiko Moji ${ }^{8}$, Shigeyuki Kano ${ }^{9}$, Hisami Watanabe ${ }^{1,10}$ and Jun Kobayashi ${ }^{11}$

\begin{abstract}
Background: Asymptomatic malaria can be observed in both stable endemic areas and unstable transmission areas. However, although much attention has been given to acute malaria infections, relatively little attention has been paid to asymptomatic malaria. Nonetheless, because the asymptomatic host serves as a reservoir for the malaria parasite, asymptomatic malaria is now recognized as an important obstacle to malaria elimination. Asymptomatic malaria is also associated with anaemia, a global public health problem with serious consequences on human health as well as social and economic development. In Lao People's Democratic Republic (Lao PDR), malaria, anaemia, and malnutrition are serious public health concerns. However, few studies have focused on the relationship between these variables. Therefore, this study investigated the relationship between asymptomatic malaria, growth status, and the prevalence of anaemia among children aged 120 months old or younger in rural villages in LaO PDR.

Methods: In December 2010 and March 2011, data were collected from five villages in Savannakhet province. Anthropometric measurements, blood samples, and malaria rapid diagnostic tests were conducted. The presence of malaria was confirmed with polymerase chain reaction assays for Plasmodium falciparum. Underweight status, stunting, and anaemia were defined according to World Health Organization standards.

Results: The mean age of participants ( $n=319)$ was 88.3 months old (Standard Deviation: 20.6, ranged from 30-119 months old), and 20 participants (6.3\%) had an asymptomatic malaria infection, 92 (28.8\%) were anaemic, 123 (38.6\%) were underweight, and 137 (42.9\%) were stunted. Stunted children were more likely to be infected with asymptomatic malaria [odds ratio (OR) 3.34, $95 \%$ confidence interval (CI) 1.25-8.93], and asymptomatic malaria was associated with anaemia [OR 5.17, $95 \% \mathrm{Cl} 1.99-13.43]$.

Conclusions: These results suggest a significant association between asymptomatic malaria and anaemia in children. Furthermore, stunted children were more likely to have lower $\mathrm{Hb}$ levels and to be infected with asymptomatic malaria than children without stunting. However, further studies examining the impact of asymptomatic malaria infection on children's nutritional and development status are necessary.
\end{abstract}

Keywords: Asymptomatic malaria, Anemia, Plasmodium falciparum, Malnutrition, Stunting, Underweight, Lao PDR

\footnotetext{
*Correspondence: takeshiak@nagano-nurs.ac.jp

${ }^{1}$ Center of Molecular Bioscineces, Tropical Biosphere Research Center,

University of the Ryukyus, Senbaru 1, Nishihara, Okinawa, Japan

Full list of author information is available at the end of the article
} 


\section{Background}

Asymptomatic malaria can be observed in both stable endemic areas and unstable transmission areas [1-5]. Although it is difficult to define asymptomatic malaria because of a lack of standard diagnostic criteria, the most widely used criteria include the presence of parasites in peripheral thick blood smears, an axillary temperature below $37.5{ }^{\circ} \mathrm{C}$, and the absence of malaria-related symptoms [6]. For an individual, an asymptomatic infection might be benefit for the host rather than no infection at all in order to keep the immunity against malaria [7-12]. However, for communities, asymptomatic hosts serve as a reservoir for the malaria parasite and, therefore, asymptomatic malaria is recognized as an important obstacle to malaria elimination [6].

Asymptomatic malaria has received less attention than symptomatic malaria in major studies [6]. However, some studies have also shown that asymptomatic malaria is associated with anaemia [3, 5, 13-19], a global public health problem with serious consequences for human health, as well as social and economic development [20]. Therefore, because asymptomatic malaria infections can last up to one year [21-23], they may seriously affect the host $[24,25]$ by causing an iron deficiency.

Studies show inconsistent results regarding the relationship between asymptomatic malaria and the growth status of children. For example, some studies have suggested that indicator of malnutrition such as stunting or underweight was associated with asymptomatic malaria, while others have not [19, 26-34]. Therefore, examining asymptomatic malaria and its association with malnutrition would be important for public health in areas where malaria coexist [27].

Anaemia, malnutrition, and malaria are all serious public health problems throughout Lao People's Democratic Republic (Lao PDR) [20,33] and particularly in the Savannakhet province located in the southeastern part of the country. In 2008, this province ranked third among all provinces in Lao PDR for the overall incidence of confirmed Plasmodium falciparum (11.5 per 1000 persons) [35]. Furthermore, wasting (low weight for height) of children in this province was benchmarked as "serious" by the World Food Programme [36].

This study aimed to investigate the relationship between asymptomatic malaria, growth status, and the prevalence of anaemia among children aged 120 months or younger in rural villages in the Savannakhet province in Lao PDR.

\section{Methods}

\section{Study site}

A cross-sectional survey was conducted in five villages in the Savannakhet province: Dong Savanh, Arai Yai, Kalouk
Kao, and Kalouk Mai in Seponne area, December 2010 and Lahanam in March 2011. In Lao PDR, both May and December are of dry season. Malaria transmission is high rainy season between May and October [37], but transmission is perennial [38].

\section{Data collection}

As a part of survey for active case detection, all villagers including adults were invited to the data collection in each village where interviews were conducted by a medical doctor, and body temperature, anthropometric measurements, and blood samples were taken by nurses. A rapid diagnostic test for malaria was also conducted, and positive participants were treated with artemisinin-based combination therapy according to country protocols. In the Lahanam area, age in months was calculated from the registered date of birth. In Seponne, participants' registered date of birth was not collected from the local administration office because of coordination problems. Then children aged less than one year old were recorded their age in month from the interview of caregiver. As the caregivers did not know the exact birth date of their children, children aged one year old or older were recorded using self-reported age in completed years. In order to calculate height for age and weight for age Z-score, the age in months were estimated by adding six months to age in completed years in order to minimize the difference from real age in months of each child.

Informed consent was obtained from the principal caregiver. The National Institute of Public Health, Ministry of Health, Lao PDR approved this study in September 2008.

\section{Definition of asymptomatic malaria, growth status, anaemia}

Asymptomatic malaria was defined as being free of fever (body temperature $\leq 37.5^{\circ} \mathrm{C}$ ) [39] and presence of malaria parasite infection and absence of any malaria related symptom at the time of data collection [40]. Malaria infection was confirmed by polymerase chain reaction (PCR) assays for $P$. falciparum in the laboratory of the University of the Ryukyus. PCR assays were conducted with the all blood samples from the eligible children regardless of the results from RDT, including negative ones. Being underweight was defined as having a weight-for-age $\mathrm{z}$ score $\leq-2$ standard deviations (SD) below the World Health Organization's (WHO) growth standards [41]. Stunting was defined as having a heightfor-age $\mathrm{z}$ score $\leq-2 \mathrm{SD}$. Anaemia was determined by haemoglobin $(\mathrm{Hb})$ levels using the HemoCue system ${ }^{\circledR}$ (HemoCue ${ }^{\circledR} \mathrm{AB}$, Ängelholm, Sweden) with a threshold of $110 \mathrm{~g} / \mathrm{L}$ for children aged $<5$ and $115 \mathrm{~g} / \mathrm{L}$ for children 
aged $\geq 5[42,43]$. Anemia was categorized as severe, moderate and mild [43].

\section{Analysis}

A total of 784 villagers with all ages (range: $0-70$ years old) participated in anthropometric measurements, blood sample collection, and malaria rapid diagnostic tests as a part of active case detection survey. In order to use the WHO growth standards for weight-by-age, children and adults aged older than 120 months were excluded from analysis $(n=427)$. Children younger than 24 months of age were excluded from anthropometric measurement due to time and equipment constrains to measure their length correctly, and take blood sample $(n=7)$. As a consequence, the data from children aged 24 months or older, and 120 months or younger $(\mathrm{n}=350)$ were included in the analysis. Among those 350 cases, data with missing data for the anthropometric or body temperature measurements, or blood collection were excluded from the analysis $(\mathrm{n}=26)$.

Five symptomatic malaria cases were also excluded. Thus, 319 children were included in the final analysis. As mentioned above, the age in months among children in Seponne area were estimated by adding 6 months to age in completed years $(\mathrm{n}=145,45.5 \%)$.

The demographic characteristics of the participants, rates of asymptomatic malaria infection, $\mathrm{Hb}$ levels, the prevalence of anaemia, weight, and height were examined. T-tests were used to compare the differences in the mean $\mathrm{Hb}$ level between boys/girls, underweight/not underweight, and stunting/no stunting. Odds ratios (OR) with $95 \%$ confidence intervals $(\mathrm{CI})$ stratified by growth status were used to examine the association between anaemia and asymptomatic malaria. A multivariate linear regression analysis with forced entry was conducted using $\mathrm{Hb}$ level as the dependent variable. The participants' age, asymptomatic malaria infection status, and growth status (stunting/underweight) were included as independent variables. To avoid multicollinearity, height and weight were input separately, and two multivariate regression models were developed: one including weight and the other including height. The significance level for statistical testing was set at $\mathrm{p}<0.05$. IBM SPSS ver. 21 was used for statistical analysis.

\section{Results}

\section{Characteristics of the participants}

The mean age of participants $(\mathrm{n}=319)$ was 88.3 months old (SD: 20.6) and ranged from 30-119 months old (Table 1). The proportion of male to female participants was approximately the same (boys $=50.2 \%$ and girls $=49.8 \%$ ). The mean $\mathrm{Hb}$ level was $119.0 \mathrm{~g} / \mathrm{L}$ (SD: 12.6). A total of 92 participants were classified as anaemic, and asymptomatic malaria infection was found in 20 participants. Among anaemic children, few cases of severe anaemia were found $(n=2)$, where almost children were mild or moderate anaemia. There was no severe anaemia case in the participants infected with asymptomatic malaria. Stunted children were more likely to be infected with asymptomatic malaria (OR 3.34, $95 \%$ CI 1.25-8.93) and there were no significant differences in growth status or the prevalence of anaemia or asymptomatic malaria between male and female participants.

\section{Key findings}

Table 2 shows the results for asymptomatic malaria, anaemia, and growth status. Among the total sample, the OR for being anaemic and having an asymptomatic malaria infection was 5.17 [95 \% CI 1.99-13.43]. The relationship remained significant for children underweight (OR 5.35, 95 \% CI 1.26-22.74), and not underweight (OR 5.00, $95 \%$ CI 1.40-17.82) and for children stunted (OR 4.18, $95 \%$ CI 1.31-13.34) and not stunting (OR 6.38, 95 \% CI 1.13-36.08).

Table 3 shows the results of the multivariate linear regression analysis. Being underweight was not significant in this model whereas stunting was, indicating that stunting was associated with a decreased $\mathrm{Hb}$ level after adjusting for asymptomatic infection.

\section{Discussion}

Among children in villages in Lao PDR, a significant association was indicated between asymptomatic malaria and the risk of anaemia and stunted children were also more likely to have an asymptomatic malaria infection. The results of the multivariate analysis also indicated that asymptomatic malaria correlated with a lower $\mathrm{Hb}$ level, and stunting was associated with the anaemia, even after adjusting for asymptomatic infection.

Although the results of present study showed that asymptomatic malaria was significantly associated with stunting, previous studies have presented inconsistent findings for this association [26, 28, 33, 44]. For example, while a previous study conducted in Lao PDR indicated that wasted children were more likely to be infected with malaria [33], in a study of Ghanaian children, stunting was not significantly associated with asymptomatic malaria [26].

Some studies suggest that children's malnutrition may have protective effects against malaria [28, 44]. Conversely, other studies suggest malnourished children seem to be more susceptible to malaria because of decreased immune system functioning [45]. For example, a reduced immunoglobulin $\mathrm{G}$ antibody response to $P$. falciparum was observed in children with malnutrition [46], and the relative risk of morbidity due to malaria 
Table 1 Characteristics of the participants $(n=319)$

\begin{tabular}{|c|c|c|c|c|c|c|}
\hline Characteristics & $\mathbf{N}$ & (\%) & Mean & SD & Asymptomatic $P f$ infection $\mathrm{N}$ & OR $(95 \% \mathrm{Cl})$ \\
\hline Age in months (total) & & & 88.3 & 20.6 & 20 & \\
\hline \multicolumn{7}{|l|}{ Range: 30-119 months } \\
\hline Male & 160 & $(50.2)$ & & & 11 & $1.23(0.50-3.06)$ \\
\hline Female & 159 & $(49.8)$ & & & 9 & 1.00 \\
\hline Height for age $Z$ score & & & -1.65 & 1.38 & & \\
\hline Male & & & $-1.65^{a}$ & 1.31 & & \\
\hline Female & & & $-1.65^{\mathrm{a}}$ & 1.44 & & \\
\hline Stunting & 137 & $(42.9)$ & & & 14 & $3.34(1.25-8.93)$ \\
\hline No stunting & 182 & $(57.1)$ & & & 6 & 1.00 \\
\hline Weight for age Z score & & & -1.66 & 1.17 & & \\
\hline Male & & & $-1.72^{b}$ & 1.10 & & \\
\hline Female & & & $-1.60^{b}$ & 1.24 & & \\
\hline Underweight & 123 & $(38.6)$ & & & 9 & $1.33(0.53-3.30)$ \\
\hline No underweight & 196 & $(61.4)$ & & & 11 & 1.00 \\
\hline Hemoglobin g/L & & & 119.0 & 12.6 & & - \\
\hline Male & & & $118.9^{c}$ & 13.4 & & - \\
\hline Female & & & $119.2^{c}$ & 11.7 & & - \\
\hline 59 months or younger & 33 & $(10.3)$ & $117.9^{d}$ & 12.4 & & \\
\hline 60 months or younger & 286 & $(89.7)$ & $119.2^{d}$ & 12.6 & & \\
\hline Anaemia & 92 & $(28.8)$ & & & 13 & $5.17(1.99-13.43)$ \\
\hline No anaemia & 227 & $(71.2)$ & & & 7 & 1.00 \\
\hline Male & 52 & $(32.5)$ & & & & $1.11(0.96-1.27)$ \\
\hline Female & 40 & $(24.2)$ & & & & 1.00 \\
\hline Severe & 2 & $(0.6)$ & & & 0 & \\
\hline Moderate & 49 & (15.4) & & & 10 & \\
\hline Mild & 41 & (12.9) & & & 3 & \\
\hline
\end{tabular}

$\mathrm{p}$ values by t test

${ }^{a} \mathrm{p}=0.99$

b $\mathrm{p}=0.36$

c $\mathrm{p}=0.81$

${ }^{d} p=0.60$

infections was higher and more consistent in children with a low body mass index [47]. In addition, a nationally representative survey conducted in Equatorial Guinea indicated that malnutrition had a significant relationship with malaria parasitaemia in children [48]. However, complex interactions between malnutrition and the risk and reaction to malaria infection have been indicated in studies [45, 47, 49]. An approach targeting not only malaria parasite but also the comprehensive health status of host such as immunity level [46] would be necessary.

In the multivariate analysis in this study, the association between stunting and anaemia remained even after adjusting for other factors. However, due to the complex relationship between malaria and anaemia, a comprehensive approach is necessary to understand $[34,49,50]$. To interpret these observations, more information, such as the duration of infection and mean parasitaemia levels, should be included in analyses [17].
Severe anaemia was not found among the participants infected with aymptomatic malaria, as in a study conducted in South Ethiopia [51]. In order to study the longitudinal effect, the severity of anaemia would be important aspect for the future observation. Although malaria has been emphasized as acute disease, studies explore chronical effect of asymptomatic malaria, such as disability-adjusted life years would be expected.

This study has several limitations. First, the crosssectional nature of the data precluded an analysis of the complex, mutual interaction between malaria infection and malnutrition [45]. This interaction is important because malaria infection leads to compromised growth and a compromised nutritional status that in turn leads to increased susceptibility to malaria infection [52]. Furthermore, malnutrition impairs the function of innate and adaptive immunity, which is important for defense against parasitic infection [53], and repeated malaria 
Table 2 Asymptomatic malaria, anemia and growth status

\begin{tabular}{|c|c|c|c|c|}
\hline & \multirow{2}{*}{$\begin{array}{l}\text { Asymptomatic } \\
\text { malaria }\end{array}$} & \multicolumn{2}{|l|}{ Anemia } & \multirow[t]{2}{*}{ OR $(95 \% \mathrm{Cl})$} \\
\hline & & No N (\%) & Yes N (\%) & \\
\hline \multirow[t]{2}{*}{ Total sample $(\mathrm{N}=319)$} & + & $7(35.0)$ & $13(65.0)$ & $5.17(1.99-13.43)^{*}$ \\
\hline & - & $220(73.6)$ & $79(26.4)$ & 1.00 \\
\hline \multicolumn{5}{|l|}{ Underweight/not underweight } \\
\hline \multirow[t]{2}{*}{ No underweight $(n=196)$} & + & $4(36.4)$ & $7(63.6)$ & $5.00(1.40-17.82)^{*}$ \\
\hline & - & $137(74.1)$ & $48(25.9)$ & 1.00 \\
\hline \multirow[t]{2}{*}{ Underweight $(n=123)$} & + & $3(33.3)$ & $6(66.7)$ & $5.35(1.26-22.74)^{*}$ \\
\hline & - & $83(72.8)$ & $31(27.2)$ & 1.00 \\
\hline \multicolumn{5}{|l|}{ Stunting/not stunting } \\
\hline \multirow[t]{2}{*}{ No stunting } & + & $2(33.3)$ & $4(66.7)$ & $6.38(1.13-36.08)^{*}$ \\
\hline & - & $134(76.1)$ & $42(23.9)$ & 1.00 \\
\hline \multirow[t]{2}{*}{ Stunting } & + & $5(35.7)$ & $9(64.3)$ & $4.18(1.31-13.34)^{*}$ \\
\hline & - & $86(69.9)$ & $37(30.1)$ & 1.00 \\
\hline
\end{tabular}

* $p<0.05$

Table 3 Multivariate linear regression analysis on hemoglobin level (g/dL)

\begin{tabular}{|c|c|c|c|}
\hline \multirow[t]{3}{*}{ Variables } & \multicolumn{3}{|c|}{ Hemoglobin level } \\
\hline & \multicolumn{2}{|c|}{$\begin{array}{l}\text { Unstandardized } \\
\text { coefficient }\end{array}$} & \multirow{2}{*}{$\begin{array}{l}\text { Standardized } \\
\text { coefficient } \\
\beta\end{array}$} \\
\hline & B & Std. error & \\
\hline \multicolumn{4}{|l|}{ Model with underweight } \\
\hline Asymptomatic Pf infection ${ }^{\mathrm{a}_{1} *}$ & -1.27 & 0.28 & -0.24 \\
\hline Age in months & 0.003 & 0.003 & 0.04 \\
\hline Underweight $^{\mathrm{a}}$ & -0.05 & 0.14 & -0.02 \\
\hline Constant* & 11.84 & 0.30 & \\
\hline \multicolumn{4}{|l|}{ Model with stunting } \\
\hline Asymptomatic Pf infection ${ }^{\mathrm{a}, *}$ & -1.19 & 0.28 & -0.23 \\
\hline Age in months & 0.003 & 0.003 & 0.05 \\
\hline Stunting ${ }^{\mathrm{a}, *}$ & -0.28 & 0.14 & -0.11 \\
\hline Constant $^{\mathrm{a}}$ & 11.87 & 0.29 & \\
\hline
\end{tabular}

a Inputted as binary variable

${ }^{*} p<0.05$

infections might lead to anaemia and chronic ill health [3]. Therefore, longitudinal studies are needed to help clarify this issue.

Second, the sample was collected by convenience sampling, and as this study was conducted during dry season, only a small proportion of the participants had an asymptomatic malaria infection. Thus, this might not be representative of other populations.

Third, data on other parasitic diseases than P. falciparum were not collected due to limited resources and time to make samples for PCR analysis and $\mathrm{Hb}$ level in the field. However, one study has shown that other parasitic diseases, such as hookworm infection, may be stronger predictors of $\mathrm{Hb}$ levels than sex, malarial parasitaemia, and Ascaris lumbricoides infection [54], while Plasmodium vivax infection has also been suggested as a predictor of anaemia [55]. Therefore, future studies should include other parasites to further explain the relationship between asymptomatic malaria and anaemia.

Fourth, children aged 120 months or younger, being asymptomatic on the day of the data collection were eligible for inclusion. Therefore, patients with anaemia caused by a recent malaria episode that had cleared by the day of the data collection [18] may have been included in the analysis.

Finally, registered age in months could not be used due to coordination problems and insufficient memory of caregivers. The date of birth is important information to evaluate the growth of children and this can be solved asking approximate date with the help of event calendar during the interview with caregiver [56]. However, such interviews could not be done due to limited time and other resources. This will limit the validity and generalization of the results of this study. Despite these limitations, this study also has several strengths. For example, although PCR is limited because deoxyribonucleic acid fragments remain in the blood for a short time and observations using the PCR technique would capture only living parasites $[57,58]$, light microscopy is not able to assess submicroscopic infections [59]. Because submicroscopic malaria infections can contribute to the prevalence of anaemia [59], and submicroscopic P. falciparum gametocyte carriers could be an infectious reservoir in areas of seasonal transmission [60, 61], PCR-based methods, rather than light microscopy, are a useful and important tool for the detection of the malarial parasite given their sensitivity to detect an infection $[62,63]$. 
In addition, most of the major studies on asymptomatic malaria have been conducted in African regions while epidemiological information on asymptomatic malaria in Asian countries has been limited [13, 33, 47, 55, 63-68]. Given that anaemia, malnutrition, and malaria are public health concerns in Lao PDR, the results of this study are clinically important for understanding the health status and nutritional problems among children in this country.

\section{Conclusions}

In this study, asymptomatic malaria was shown to be associated with anaemia in children, and stunted children were more likely to have lower Hb levels. However, further studies are necessary to understand the impact of asymptomatic malaria on the health status of children in Lao PDR.

\section{Abbreviations}

$\mathrm{Cl}$ : confidence interval; Hb: haemoglobin; Lao PDR: Lao People's Democratic Republic; OR: odds ratio; PCR: polymerase chain reaction; SD: standard deviations; WHO: World Health Organization.

\section{Authors' contributions}

TA carried out the field research, analyzed the data, and wrote the manuscript. TT supervised and conducted the field and laboratory tests. YI and RT carried out the laboratory tests. TW supervised the laboratory tests. HN and KM supervised the field activities. SK, TP and SP supervised the field and laboratory tests. HW supervised the field and laboratory tests as well as the manuscript writing. JK supervised the manuscript writing. All authors read and approved the final manuscript.

\section{Author details \\ ${ }^{1}$ Center of Molecular Bioscineces, Tropical Biosphere Research Center, Univer- sity of the Ryukyus, Senbaru 1, Nishihara, Okinawa, Japan. ${ }^{2}$ Nagano College of Nursing, Komagane, Nagano, Japan. ${ }^{3}$ Station of Malariology, Parasitology and Entomology, Savannakhet Health Department, Savannakhet, Lao People's Democratic Republic. ${ }^{4}$ National Institute of Public Health, Ministry of Health, Vientiane Capital, Lao People's Democratic Republic. ${ }^{5}$ Center for Medical Edu- cation, Graduate School of Medicine, Gunma University, Maebashi, Gunma, Japan. ${ }^{6}$ Institute of Tropical Medicine, Nagasaki University, Nagasaki, Nagasaki, Japan. ${ }^{7}$ Department of Cell Biology, Kyoto Pharmaceutical University, Kyoto, Japan. ${ }^{8}$ School of Tropical Medicine and Global Health, Nagasaki University, Nagasaki, Nagasaki, Japan. ${ }^{9}$ Research Institute, National Center for Global Health and Medicine, Tokyo, Japan. ${ }^{10}$ Graduate School of Medical and Den- tal Sciences, Niigata University, Niigata, Niigata, Japan. ${ }^{11}$ Graduate School of Medicine, University of the Ryukyus, Nishihara, Okinawa, Japan.}

\section{Acknowledgements}

We thank all the staff of National Institute of Public Health, Ministry of Health, Lao PDR for their participation and cooperation in this study. This work was supported by The Grant for National Center for Global Health and Medicine (22A-3, 25A-2, 28A-4).

\section{Competing interests}

The authors declare they have no competing interests.

\section{Availability of data and materials}

Our datasets and data definition are available from University of the Ryukyus' data archive to other research groups upon reasonable request.

\section{Ethics approval and consent to participate}

Informed consent was obtained from the principal caregiver. The National Institute of Public Health, Ministry of Health, Lao PDR approved this study in September 2008.
Received: 2 May 2016 Accepted: 5 October 2016

Published online: 18 October 2016

\section{References}

1. Baliraine FN, Afrane YA, Amenya DA, Bonizzoni M, Menge DM, Zhou G, et al. High prevalence of asymptomatic Plasmodium falciparum infections in a highland area of western Kenya: a cohort study. J Infect Dis. 2009;200:66-74.

2. Cerutti C Jr, Boulos M, Coutinho AF, Hatab MC, Falqueto A, Rezende HR, et al. Epidemiologic aspects of the malaria transmission cycle in an area of very low incidence in Brazil. Malar J. 2007;6:33.

3. Bin Mohanna MA, Bin Ghouth AS, Raja'a YA. Malaria signs and infection rate among asymptomatic school children in Hajr valley, Yemen. East Mediterr Health J. 2007;13:35-40.

4. Stresman GH, Kamanga A, Moono P, Hamapumbu H, Mharakurwa S, Kobayashi T, et al. A method of active case detection to target reservoirs of asymptomatic malaria and gametocyte carriers in a rural area in Southern Province Zambia. Malar J. 2010;9:265.

5. Nzobo BJ, Ngasala BE, Kihamia CM. Prevalence of asymptomatic malaria infection and use of different malaria control measures among primary school children in Morogoro Municipality, Tanzania. Malar J. 2015;14:491.

6. Laishram DD, Sutton PL, Nanda N, Sharma VL, Sobti RC, Carlton JM, et al. The complexities of malaria disease manifestations with a focus on asymptomatic malaria. Malar J. 2012;11:29.

7. Kinyanjui SM, Bejon P, Osier FH, Bull PC, Marsh K. What you see is not what you get: implication of the brevity of antibody responses to malaria antigens and transmission heterogeneity in longitudinal studies of malaria immunity. Malar J. 2009;8:242.

8. Bejon P, Warimwe G, Mackintosh CL, Mackinnon MJ, Kinyanjui SM, Musyoki JN, et al. Analysis of immunity to febrile malaria in children that distinguish immunity from lack of exposure. Infect Immun. 2009;77:1917-23.

9. Bereczky S, Liljander A, Rooth I, Faraja L, Granath F, Montgomery SM, et al. Multiclonal asymptomatic Plasmodium falciparum infections predict a reduced risk of malaria disease in a Tanzanian population. Microbes Infect. 2007;9:103-10

10. Kinyanjui SM, Mwangi T, Bull PC, Newbold Cl, Marsh K. Protection against clinical malaria by heterologous immunogloblin $\mathrm{G}$ antibodies against malaria-infected erythrocyte variant surface antigens requires interaction with asymptomatic infections. J Infect Dis. 2004;190:1527-33.

11. Cornet M, Le Hesran JY, Fievet N, Cot M, Personne P, Gounoue R, et al. Prevalence of and risk factors for anemia in young children in southern Cameroon. Am J Trop Med Hyg. 1998;58:606-11.

12. Males S, Gaye O, Garcia A. Long-term asymptomatic carriage of Plasmodium falciparum protects from malaria attacks: a prospective study among Senegalese children. Clin Infect Dis. 2008;15:516-22.

13. Das BS, Thurnham DI, Das DB. Influence of malaria of iron status in children: implications for interpreting iron status in malaria-endemic communities. Br J Nutr. 1997;78:751-60.

14. de Mast Q, Syafruddin D, Keijmel S, Riekerink TO, Deky O, Asih PB, et al. Increased serum hepcidin and alterations in blood iron parameters associated asymptomatic P. falciparum and P. vivax malaria. Haematologica. 2010;95:1068-74.

15. Prentice AM, Cox SE, Nweneka CV. Asymptomatic malaria in the etiology of iron deficiency anemia: a nutritionist's viewpoint. Am J Clin Nutr. 2010;92:1283-4.

16. Jeremiah ZA, Uko EK, Buseri Fl, Jeremiah TA. Malaria iron-deficiency anaemia among asymptomatic Nigerian children. J Nutr Environ Med. 2007; 16:232-41.

17. McElroy PD, ter Kuile FO, Lal AA, Bloland PB, Hawley WA, Oloo AJ, et al Effect of Plasmodium falciparum parasitemia density on hemoglobin concentrations among full-term, normal birth weight children in western Kenya, IV. The Asembo Bay Cohort Project. Am J Trop Med Hyg. 2000;62:504-12.

18. Kurtzhals JA, Addae MM, Akanmori BD, Dunyo S, Koram KA, Appawu MA, et al. Anaemia caused by asymptomatic Plasmodium falciparum infection in semi-immune African school children. Trans R Soc Trop Med Hyg. 1999:93:623-7. 
19. Leenstra T, Phillips-Howard PA, Kariuki SK, Hawley WA, Alaii JA, Rosen $\mathrm{DH}$, et al. Permethrin-treated bed nets in the prevention of malaria and anemia in adolescent school girls in western Kenya. Am J Trop Med Hyg. 2003;68:86-93.

20. World Health Organization. Worldwide prevalence of anemia 1993-2005. http://www.who.int/vmnis/publications/anaemia_prevalence/en/index. html (2008). Accessed 22 Aug 2012.

21. Baliraine FN, Afrane YA, Amenya DA, Bonizzoni M, Menge DM, Zhou G, et al. High prevalence of asymptomatic Plasmodium falciparum infections in a highland area of Western Kenya: a Cohort study. J Infect Dis. 2009;200:66-74

22. Nassir E, Abdel-Muhsin A-MA, Suliaman S, Kenyon F, Kheir A, Geha H, et al. Impact of genetic complexity on longevity and gametocytogenesis of Plasmodium falciparum during the dry and transmission-free season of eastern Sudan. Int J Parasitol. 2005;35:49-55.

23. Franks S, Koram KA, Wagner GE, Tetteh K, McGuinness D, Wheeler JG, et al. Frequent and persistent, symptomatic Plasmodium falciparum infections in African Infants, characterized by multilocus genotyping. J Infect Dis. 2001;183:796-804.

24. Verfoef H. Asymptomatic malaria in the etiology of iron deficiency anemia: a malariologist's viewpoint. Am J Clin Nutr. 2010;92:1285-6.

25. Shankar AH. Malaria and nutrition. In: Semba RD, Bloem MW, editors. Nutrition and Health in Developing Countries. 2nd ed. New Jersey: Humana Press; 2008. p. 229-74.

26. Crookston BT, Alder SC, Boakye I, Merrill RM, Amuasi JH, Porucznik CA, et al. Exploring the relationship between chronic undernutrition and asymptomatic malaria in Ghanaian children. Malar J. 2010;9:39.

27. Friedman JF, Kwena AM, Mirel LB, Kariuki SK, Terlouw DJ, Phillips-Howard PA, et al. Malaria and nutritional status among pre-school children: results from cross-sectional surveys in western Kenya. Am J Trop Med Hyg. 2005;73:698-704

28. Genton B, Al-Yaman F, Ginny M, Taraika J, Alpers MP. Relation of anthropometry to malaria morbidity and immunity in Papua New Guinean children. Am J Clin Nutr. 1998;68:734-41.

29. Kahigwa E, Schellenberg D, Sanz S, Aponte JJ, Wigayi J, Mshinda H, et al. Risk factors for presentation to hospital with severe anaemia in Tanzanian children: a case-control study. Trop Med Int Health. 2002;7:823-30.

30. Mamiro PS, Kolsteren P, Roberfroid D, Tatala S, Opsomer AS, Van Camp JH. Feeding practices and factors contributing to wasting, stunting, and irondeficiency anaemia among 3-23-month old children in Kilosa district, rural Tanzania. J Health Popul Nutr. 2005;23(3):222-30.

31. Nkuo-Akenji TK, Sumbele I, Mankah EN, Njunda AL, Samje M, Kamga $\mathrm{L}$. The burden of malaria and malnutrition among children less than 14 years of age in a rural village of Cameroon. Afr J Food Agric Nutr Dev. 2008;8:252-64.

32. Shiff C, Checkley W, Winch P, Premji Z, Minjas J, Lubega P. Changes in weight gain and anaemia attributable to malaria in Tanzanian children living under holoendemic conditions. Trans R Soc Trop Med Hyg. 1996;90:262-5

33. Takakura M, Uza M, Sasaki Y, Nagahama N, Phommpida S, Bounyadeth S, et al. The relationship between anthropometric indicators of nutritional status and malaria infection among youths in Khammouane Province, Lao PDR. Southeast Asian J Trop Med Public Health. 2001;32:262-7.

34. Verhoef H, West CE, Veenemans J, Beguin Y, Kok FJ. Stunting may determine the severity of malaria-associated anemia in African children. Pediatrics. 2002;110:4

35. Jorgensen P, Nambanya S, Gopinath D, Hongvanthong B, Luangphengsouk K, Bell D, et al. High heterogeneity in Plasmodium falciparum risk illustrates the need for detailed mapping to guide resource allocation: a new malaria risk map of the Lao People's Democratic Republic. Malar J. 2010;9:59.

36. World Food Programme: World Food Program Lao PDR country strategy 2011-2015. http://www.wfp.org/content/lao-pdr-country-strategyENG. pdf. Accessed 22 Aug 2011.

37. Rattanaxay P, Phompida S, Kobayashi J. A review of malaria situation and its control in Lao PD. Asian Parasitology. 2005;6:85-104.

38. Kobayashi J, Somboon P, Keomanila H, Inthavongsa S, Nambanya S, Inthakone S, et al. Malaria prevalence and a brief entomological survey in a village surrounded by rice fields in Khammouan province Lao PDR. Trop Med Int Health. 2000;5:17-21.
39. World Health Organization. Guidelines for the treatment of malaria, 3rd edition. http://www.who.int/malaria/publications/atoz/9789241549127/ en/ (2015). Accessed 17 Sep 2016.

40. Laishram DD, Sutton PL, Nanda N, Sharma VL, Sobti RC, Carlton JM, et al. Th205e complexities of malaria disease manifestations with a focus on asymptomatic malaria. Malar J. 2012;11:29

41. World Health Organization. WHO child growth standards: training course on child growth assessment. C. Interpreting growth indicators. http:// www.who.int/childgrowth/training/module_c_interpreting_indicators. pdf (2008). Accessed 22 Aug 2011.

42. World Health Organization, United Nations Children's Fund, United Nations University (2001). Iron deficiency anemia: assessment, prevention, and control. A guide for program managers. http://whqlibdoc.who. int/hq/2001/WHO_NHD_01.3.pdf Accessed 22 Aug 2012.

43. World Health Organization (2011) Haemoglobin concentration for the diagnosis of anaemia and assessment of severity. http://apps.who.int/ iris/bitstream/10665/85839/3/WHO_NMH_NHD_MNM_11.1_eng.pdf Accessed 17 Sep 2016

44. Senga EL, Harper G, Koshy G, Kazembe PN, Brabin BJ. Reduced risk for placental malaria in iron deficient woman. Malar J. 2001;10:47.

45. Schaible UE, Kaufmann SH. Malnutrition and infection: complex mechanisms and global impacts. PLoS Med. 2007:4:e115.

46. Fillol F, Sarr JB, Boulanger D, Cisse B, Sokhna C, Riveau G, et al. Impact of child malnutrition on the specific anti-Plasmodium falciparum antibody response. Malar J. 2009;8:116.

47. Ramachandran P, Gopalan HS. Undernutrition \& risk of infections in preschool children. Ind J Med Res. 2009:130:579-83.

48. Custodio E, Descalzo MA, Villamor E, Molina L, Sánchez I, Lwanga M, et al. Nutritional and socio-economic factors associated with Plasmodium falciparum infection in children from Equatorial Guinea: results from a nationally representative survey. Malar J. 2009;8:225.

49. Verhoef $H$, West CE, Ndeto P, Burema J, Beguin Y, Kok FJ. Serum transferrin receptor concentration indicates increased erythropoiesis in Kenyan children with asymptomatic malaria. Am J Clin Nutr. 2001;74:767-75

50. Haldar K, Mohandas N. Malaria, erythrocytic infection, and anemia. Hematology. 2009;2009(1):87-93.

51. Neda D, Dana D, Tefera T, Eshetu T. Anemia associated with asymptomatic malaria among pregnant women in the rural surroundings of Arba Minch Town, South Ethiopia. BMC Res Notes. 2015:8:110.

52. Holding PA, Kitsao-Wekulo PK. Describing the burden of malaria on child development: what should we be measuring and how should we be measure it? Am J Trop Med Hyg. 2004;71:71-9.

53. Hughes S, Kelly P. Interactions of malnutrition and immune impairment, with specific reference to immunity against parasites. Parasite Immunol. 2006:28:577-88.

54. Stoltzfus RJ, Chwaya HM, Tielsch JM, Schulze KJ, Albonico M, Savioli L. Epidemiology of iron deficiency anemia in Zanzibari schoolchildren: the importance of hookworms. Am J Clin Nutr. 1997:65:153-9.

55. Dreysuss ML, Stoltzfus RJ, Shrestha JB, Pradhan EK, LeClerq SC, Khatry SK, et al. Hookworms, malaria and vitamin A deficiency contribute to anemia and iron deficiency among pregnant women in the plains of Nepal. J Nutr. 2000;130:2527-36.

56. World Health Organization. WHO AnthroPlus for personal computers manual. http://www.who.int/growthref/tools/who_anthroplus_manual. pdf Accessed 17 Sep 2016.

57. Dal-Bianco MP, Köster KB, Kombila UD, Kun JFJ, Grobusch MP, Ngoma GM, et al. High prevalence of asymptomatic Plasmodium falciparum infections in Gabonese adults. Am J Trop Med Hyg. 2007;77:939-42.

58. Jarra W, Snounou G. Only viable parasites are detected by PCR following clearance of rodent malarial infections by drug treatment or immune responses. Infect Immun. 1998:66:3783-7.

59. Ladeia-Andrade S, Ferreira MU, de Carvalho ME, Curado I, Coura JR. Age-dependent acquisition of protective immunity to malaria in riverine populations of the Amazon Basin of Brazil. Am J Trop Med Hyg. 2009;80:452-9.

60. Ouédraogo AL, Bousema T, Schneider P, de Vlas SJ, Ilboudo-Sanogo E, Cuzin-Ouattara N, et al. Substantial contribution of submicroscopical Plasmodium falciparum gametocyte carriage to the infectious reservoir in an area of seasonal transmission. PLOS ONE. 2009:4:12. 
61. Roshhanravan B, Kari E, Gilman RH, Cabrera L, Lee E, Metcalfe J, et al. Endemic malaria in the Peruvian Amazon region of lquitos. Am J Trop Med Hyg. 2003;69:45-52.

62. Wu L, van den Hoogen LL, Slater H, Walker PGT, Ghani AC, Drakeley CJ, et al. Comparison of diagnostics for the detection of asymptomatic Plasmodium falciparum infections to inform control and elimination strategies. Nature. 2015;528:S86-93.

63. Imwong M, Nguyen TN, Tripura R, Peto TJ, Lee SJ, Lwin KM, et al. The epidemiology of subclinical malaria infections in South-East Asia: findings from cross-sectional surveys in Thailand-Myanmar border areas, Cambodia, and Vietnam. Malar J. 2015;14:381.

64. Baum E, Sattabongkot J, Sirichaisinthop J, Kiattibutr K, Davies DH, Jain A, et al. Submicroscopic and asymptomatic Plasmodium falciparum and Plasmodium vivax infections are common in western Thailand-molecular and serological evidence. Malar J. 2015;14:95.
65. Smith Gueye C, Sanders KC, Galappaththy GN, Rundi C, Tobgay T, Sovannaroth $\mathrm{S}$, et al. Active case detection for malaria elimination: a survey among Asia Pacific countries. Malar J. 2013;12:358.

66. Steenkeste N, Rogers WO, Okell L, Jeanne I, Incardona S, Duval L, et al. Sub-microscopic malaria cases and mixed malaria infection in a remote area of high malaria endemicity in Rattanakiri province, Cambodia: implication for malaria elimination. Malar J. 2010;9:108.

67. Tengco LW, Rayco-Solon P, Solon JA, Sarol JN Jr, Solon FS. Determinants of anemia among preschool children in the Philippines. J Am Coll Nutr. 2008;27:229-43.

68. Soe-Soe, Khin-Saw-Aye, Htay-Aung, Nay-Win, Tin-Aung, Than-Swe, et al. Premunition against Plasmodium falciparum in a malaria hyperendemic village in Myanmar. Trans R Soc Trop Med Hyg. 2001;95:81-4

\section{Submit your next manuscript to BioMed Central and we will help you at every step:}

- We accept pre-submission inquiries

- Our selector tool helps you to find the most relevant journal

- We provide round the clock customer support

- Convenient online submission

- Thorough peer review

- Inclusion in PubMed and all major indexing services

- Maximum visibility for your research

Submit your manuscript at www.biomedcentral com/submit 